\title{
t.……
}

\author{
ファイバによる光パワー伝送の医療への応用 \\ 佐藤 俊一, 荒井 恒憲 $*$ \\ 防衛医科大学校防衛医学研究センター情報システム研究部門（テ359-8513 埼玉県所沢市並木 3-2) \\ *防衛医科大学校医用電子工学講座（テ 359-8513 埼玉県所沢市並木 3-2）
}

\section{Medical Applications of Fiber-Based Optical Power Delivery}

\author{
Shunichi SATO and Tsunenori ARAI* \\ Division of Biomedical Information Sciences, National Defense Medical College Research Institute \\ 3-2 Namiki, Tokorozawa, Saitama 359-8513 \\ *Department of Medical Engineering, National Defense Medical College, 3-2 Namiki, Tokorozawa, Saitama 359-8513
}

(Received December 21, 1998)

\begin{abstract}
This paper reviews the current status of fiber-based optical power delivery for medicine and its applications to minimally invasive therapeutics and diagnostics. Quartz glass fibers, hollow fibers, and infrared glass/crystalline fibers are used for the power transmission of medical lasers. The characteristics of these fibers and fiber-based medical laser devices are described. For clinical applications, fibers are used in combination with catheters, endoscopes, or cannulas. Catheter-based applications include laser angioplasty, laser thrombolysis, and PTMR (Percutaneous Trans-Myocardial Revascularization). The endoscope allows the delivery of optical power not only for coagulation but also for tissue removal (ablation). Endoscopes for PDT (PhotoDynamic Therapy) are also developed. For cannula-based applications, PLDD (Percutaneous Laser Disk Decompression), ILCP (Interstitial Laser Coagulation of Prostate), and TUBAL-T (TransUrethral Balloon Thermotherapy) are described. For use in fiber-based optical biopsies, the principle and apparatus of a fluorescence imaging system for early cancer detection and an OCT (Optical Coherence Tomography) are introduced.
\end{abstract}

Key Words: Optical fiber, Medical laser, Minimally invasive therapeutics, Endoscope, Optical biopsy

1.はじめに

レーザー光を用いた治療や生体計測・診断は, 低侵襲あ るいは無侵襲であること(生体に与える損傷が小さいまた は無いこと)が大きな特長とされている。しかしながらそ の特長を十分に発揮するためには, レーザー光を生体の所 望の部位に自在に伝送するための光ファイバの存在がな くてはならない.レーザー光を循環器や呼吸器, 消化器な ど,生体の深部に誘導するためにはファイバ伝送技術が不 可欠である。また皮膚など生体の表面を対象とする治療 や計測の場合においても, 操作性の観点からファイバの利 用が強く望まれる。このようにレーザーの医療応用にお いて,ファイバ伝送技術は極めて重要な位置づけにある.

しかし言うまでもなく, 全ての医療用レーザー光がファ イバ伝送可能というわけではない. そこには自ずとファ イバの光学的, 物理的, 化学的制約があり, また安全性も重 要な因子となる。これらに鑑み, 本稿では医療用レーザー とそのファイバ伝送技術の現状および応用について概観 してみたい.

\section{2. 各種医療用光ファイバと装置}

実用化している代表的な医療用レーザーで, 現在, 最も波 長が短いものは193nmの ArFエキシマレーザー, また最も波

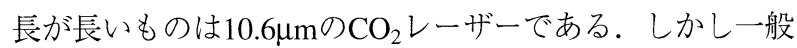
に, 光学材料の透過損失は, 赤外の長波長側では多音子吸収 により,また紫外の短波長側では電子吸収やレイリー散乱 によりそれぞれ指数関数的に増大する。このため短波長 側, 長波長側の何れにおいても, 低損失なファイバ材料は 得にくく, 実際, 上記二種のレーザー光の充実型ファイバ による伝送は困難である(一部 $\mathrm{CO}_{2}$ レーザー用結晶ファイ バは有り). 現在, 医療用レーザーの伝送に用いられている のは主として光通信用に開発された石英ガラスファイバ であり,伝送可能な波長帯域はおおよそ300nm〜2 $2 \mu \mathrm{m}$ であ る. $2 \mu \mathrm{m}$ 以上の中赤外レーザー光の伝送用としては, 中空 ファイバや赤外ファイバの開発が進められており,一部実 用化している。 また193nm ArFエキシマレーザー光の伝送 にも中空ファイバの開発が進められている。ここではこれ ら石英ガラスファイバ, 中空ファイバ, 赤外ファイバの現状 と,それらを用いた医療装置の例について紹介する。 


\section{1 石英ガラスファイバ}

上記より, 石英ガラスファイバ(以下単に石英ファイバと いう)による伝送は, 短波長側は308nm XeClエキシマレー ザーが，また長波長側は2.1 $\mu \mathrm{m}$ Ho:YAGレーザーが限界で ある、Ho:YAGレーザーは, 通常の石英ファイバにより, 実 用的な伝送効率で200 $500 \mathrm{~J} / \mathrm{cm}^{2}$ 程度の伝送が可能であ る. 一方, 石英ファイバに紫外レーザー光を入射すると, 格 子欠陥が誘起され色中心の形成により透過損失の低下を 招く。これを自己修復する目的で, B, F, OH基等を添加し た石英ファイバが開発されている。また $\mathrm{XeCl} キ シ マ$ レーザー伝送では, ファイバ材料のレーザー損傷を防止す るために長パルス化 $(>200 \mathrm{~ns}) し$, ピークパワーを低減す ることにより光強度 $2 \sim 8 \mathrm{~J} / \mathrm{cm}^{2}$ での伝送を行っている1).し かしこれらのレーザー光の石英ファイバ伝送は,伝送距離 $2 \sim 3 \mathrm{~m}$ の通常の医療用伝送条件 (許容透過損失 $0.5 \mathrm{~m} / \mathrm{dB}$ ) の場合のみ可能であり,病院内に光配線を行い長距離伝送 するようなことは現在の技術ではできない。一方, 可視や 近赤外のレーザー光は,ピークパワーが著しく高いような 場合を除けば, 必要に応じてある程度の長距離伝送を行う ことも可能である.193nm ArFレーザーは角膜の精密蒸散 等に使用する重要なレーザーであるが, この波長での石英 ファイバの伝送損失は高く,またレーザーの発振機構上長 パルス化も困難なため, 石英ファイバ伝送は事実上不可能 である。

石英ファイバは低損失であるばかりでなく, 耐熱性や機 械的強度が高く, 化学的にも安定である等多くの特長があ ることから広く利用されているのであるが,一方で, 開口 数が低いこと,および剛性が高いことなどが久点としてあ げられる，通常の医療用石英ファイバの開口数は 0.2 程度 であり,屈曲時に漏孔光によるケーブルの破壊(さらには内 視鏡やカテーテルの破壊) が発生する危険性がある。また 出射開口数の大きい半導体レーザー光の伝送には対応で きなかった。そこでファイバコアにGeなどの高屈折率物 質を添加したり,クラッドを低屈折率の樹脂とすることに より開口数 0.45 程度の石英ファイバが開発され，半導体 レーザー治療器の伝送に使われている(Fig.1 $)^{2)}$. また口径

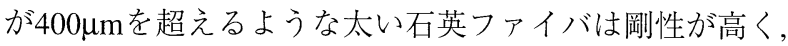
このような柔軟性の低いファイバの利用は, 管腔壁や血管 を傷つけたり,穿孔したりする原因となる。一方体内での 使用では, 通常, ファイバ出射端と照射組織間の距離をほ とんど取れないために, 接触照射(厳密には接触せず近接し ているものも含む)の形になり,照射直径はファイバコア径 とほぼ等しくなる。したがって速い治療を行う観点から は,太いファイバの使用が望ましい. 血管内治療用に開発 されたマルチファイバカテーテル (Multi-Fiber Catheter) は ビームを多数本 (20〜200本)の細径ファイバに分割して伝 送を行うもので, 高コスト, 低入射効率などの問題はある ものの, 非常に柔軟で照射面積の大きいファイバ伝送路を 実現している(Fig.4参照 $)^{3)}$.

\section{2 中空ファイバ}

前述したように, 赤外域においては波長が長くなるに従 い低損失の透過光学材料が得られにくくなる. $\mathrm{CO}_{2}$ レー

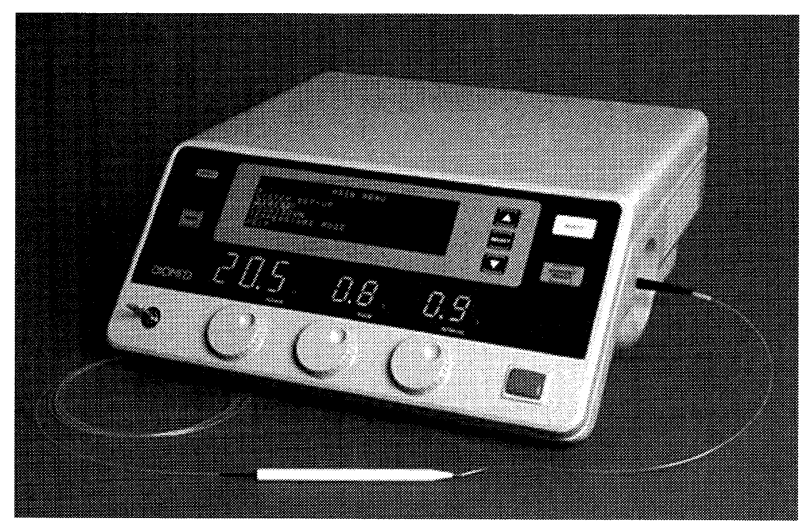

Fig.1 Photograph of the surgical diode laser with a high $N A$ silica glass fiber (Diomed 25, Olympus).

ザー伝送用光ファイバ(結晶ファイバ, ガラスファイバ)の 開発にはこれまで膨大な努力が積み重ねられてきたが, 実 用化に成功したのはごく一部であり, 実用伝送パワーも $10 \mathrm{~W}$ 程度に制限されている(2.3参照)。より高出力のパ ワー伝送を行うには, 最近では中空ファイバを用いるのが 主流となっており, 誘電体内装型中空ファイバ, 単結晶サ ファイヤ中空ファイバにより, 実験レベルながら $\mathrm{kW}$ 級の伝 送も達成されている4). ガラスファイバに比較すると曲げ 特性にやや劣るため, 内視鏡下の使用は困難であるが, レー ザー損傷しきい值が高いこと, 構造上伝送路内のガス環流 が可能なため熱発生が大きい入射・出射部分の冷却が可 能であること等の利点があり, 低出力 $\mathrm{CO}_{2}$ レーザー手術装 置の伝送路として導入が始まっている(Fig.2). 原理的に 任意の波長での設計が可能なため, COレーザー5), Er:YAG レーザー5), エキシマレーザー伝送用の中空ファイバも研 究が進められている。また最近では, Qスイッチ $\mathrm{Nd}: \mathrm{YAG}$ レーザーなど, 蒸散用高ピークパワーレーザー光の伝送路

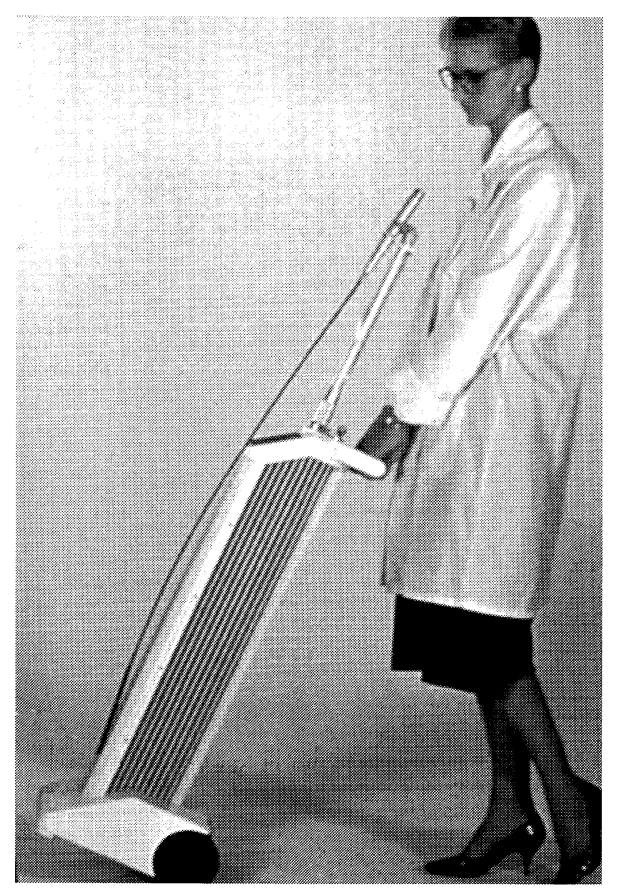

Fig.2 Photograph of the carbon dioxide laser for dental applications with a hollow fiber (LX-20, Luxar). 
としても適用の検討が始められている。

\section{3 赤外ファイバ}

石英ファイバ伝送の困難な波長 $2 \mu \mathrm{m}$ 以上のレーザー光

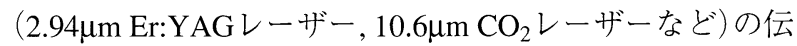
送用に, 上記中空ファイバの他, 赤外ファイバが開発され ている．Er:YAGレーザー光伝送用に実用化したのはAIF を主成分とするフッ化物ガラスファイバで, 歯科治療用に 出射端に扔いて平均出力 $5 \mathrm{~W}$ 程度の伝送が可能である $(\mathrm{Fig} .3)^{6)}$.また $\mathrm{CO}_{2}$ レーザー光伝送用として実用化してい るのは $\mathrm{AgCl} / \mathrm{AgBr}$ のコア・クラッド構造を持つ結晶ファイ バで, 消化器内視鏡下に出射端に扔いて常用平均出力 $10 \mathrm{~W}$ 程度の伝送が可能である77. 一般に, 赤外透過光学材料は 石英ガラスと比較すると低融点, 低機械強度であるという 欠点があり,これらを補うためにシール構造を有するケー ブル化を行っている.

\section{3. 治療への応用}

ファイバ伝送路の使用は治療(外科術)における操作性 の向上に重要である。外科術は現在でも全く自動化され て㧍らず,術者の手技を最大限発揮するような使いやすい 道具が求められている. 多関節式マニピュレータ光伝送 路は, 軽量化, 細径化など数々の改良が行われているにも 関わらず,その操作には慣れが要求される。直線的にビー ムを大きく動かそうとすると,その動きに追従するように 関節がビーム運動方向とは別方向の動きを起こし,その慣 性モーメントによって滑らかなビーム移動が困難にな

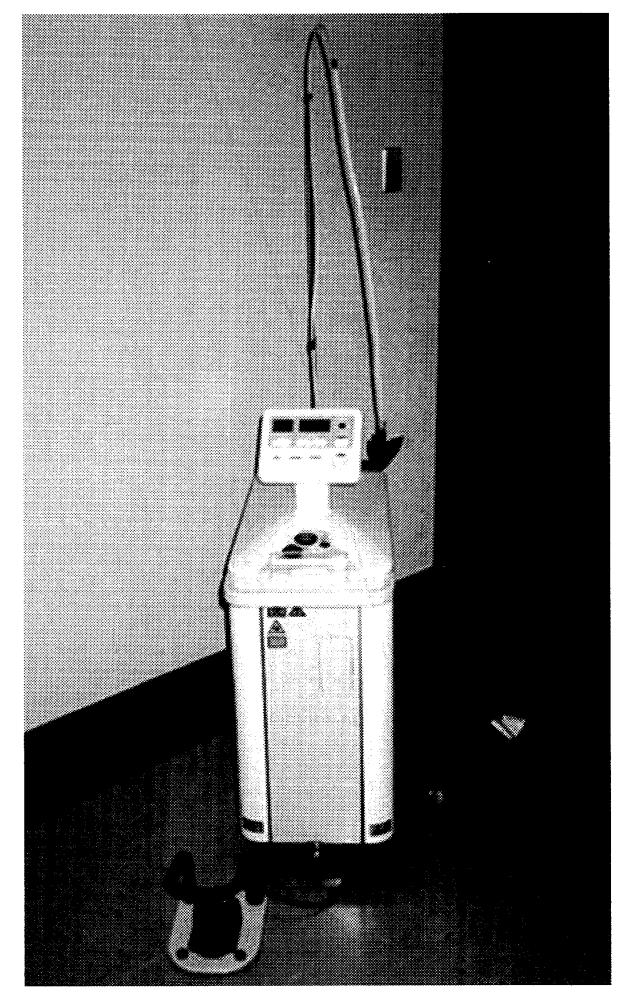

Fig.3 Photograph of the Er:YAG laser equipment for dental applications with a fluoride glass fiber (ML-5, Hoya).
る.ファイバの操作感は, 多関節式マニピュレータ伝送路 と比較し著しく優れている. 多関節式マニピュレータ伝 送路に比べて劣っていたファイバ伝送光の集光特性は, ファイバの小口径化などの工夫により以前より改善され ている. 治療器では, 平均出力ゃピークパワーの著しく高 いレーザー光の伝送を要求されるような特殊な場合を除 いては, コスト面で可能であれば, ファイバを中心とした フレキシブル伝送路を装備するようになってきている. 術野が狭い口腔内(歯科, 口腔外科)をはじめ, 開胸, 開腹を 行う外科術でも術野の直視が困難な部分(例えば泌尿器科 の前立腺手術)の治療にはファイバ伝送路が必要である.

ここでは体内にレーザーエネルギーを誘導して行う治 療を,レーザー光の経路により,血管内を通す経カテーテ ル治療, 消化管などの管腔を通す経内視鏡治療, 直線的に 針で刺入する穿刺治療の三つに分け，それぞれの現状につ いて紹介する。

\section{1 経カテーテル治療}

経カテーテル治療はファイバの柔軟性を最もよく活か した治療法と言える。またファイバ材料が誘電体である ことは,心臟と電解液(血液)で直接つながっている血管内 で,電撃(感電)事故を防ぐ観点から重要である.

実用化している経カテーテル治療の一つに, 動脈硬化に よる狭窄性病変をレーザー蒸散によって広げて血流を確 保する動脈内レーザー手術 (Laser Angioplasty)がある. 適 用部位は冠状動脈および下肢動脈(腸骨動脈, 大腿動脈, 膝 下動脈)の動脈硬化による狭窄部分であり, 対象病名として は狭心症, 間欠性跛行 (はこう)がある。冠状動脈は細く屈 曲しているので柔軟なマルチファイバカテーテルを用い る(Fig.4) ${ }^{3)}$.

別に, 血栓を除去するためにレーザー血栓除去術 (Laser Thrombolysis)が検討されている $\left.(\mathrm{Fig} .5)^{8}\right)$. 血栓は主に動脈 硬化による狭窄部分に発生し,数分から数時間で血管を完 全に閉塞する。冠状動脈血管の場合, 急性心筋梗塞の直接 原因となるため, 速やかな血栓除去が必要である。従来よ り薬殽による溶解療法があるが,レーザー血栓除去術では パルスレーザー照射によって発生する音波によって血栓 を速やかに細かく砕き除去する，大きな血栓が末梢に流 れると,小さな動脈に詰まり完全な閉塞(塞栓)を起こす危 険があるので, 細かく破砕することが極めて重要である.

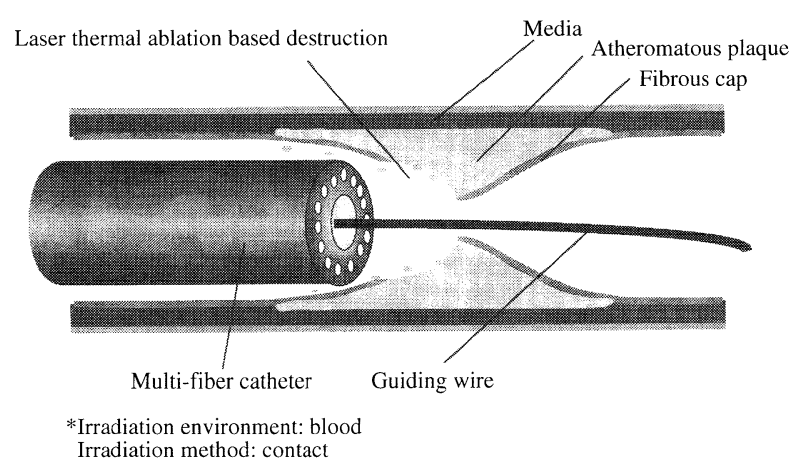

Fig.4 Diagram of laser angioplasty with a multi-fiber catheter on the guiding wire. 


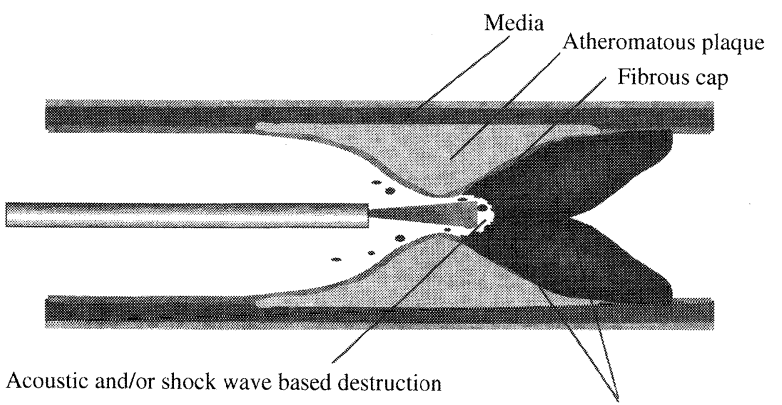

Thrombus (red, white or mixed)

*Irradiation environment: blood

Irradiation method: contact or adjacent

Fig.5 Diagram of laser thrombolysis

最近, 冠状動脈の各種内科治療, 外科治療でも救命でき ない重篤な心筋梗塞患者の治療法として,心筋にレーザー で多数の貫通孔を開け血行を確保する方法が実用化され ている (L-TMR: Laser Trans-Myocardial Revascularization). この方法は開胸外科術中に行い, 心臓の鼓動がある状態に おいて心電図同期で高出力 $(\sim 800 \mathrm{~W}) \mathrm{CO}_{2}$ レーザー光を照 射して左室に貫通孔を開ける(Fig.6 ${ }^{9)}$. 貫通孔からの出血 は圧迫止血する．高出力で焦点深度の大きい集光が必要 なためファイバは使用されていないが, 手術侵襲を小さく するために, 経カテーテル的に心臓の内側から外側に孔を 開ける術式も検討されている (PTMR: Percutaneous TransMyocardial Revascularization) (Fig.6) ${ }^{10)}$ 。この場合は止血手 段が無いため, 心筋を貫通しないようにレーザー蒸散孔を 開設するが, 主として石英ファイバ伝送したHo:YAGレー ザーが検討の対象となっている．TMR治療の原理は完全 には解明されていないが, 治療直後には開けた孔を通して 左室から直接, また慢性期にはレーザーで開けた孔の周囲 に新生血管網が形成され心筋への血液環流があると考え られている(Fig.7 $)^{11)}$.

\section{2 経内視鏡治療}

内視鏡には, フレキシブルな画像伝送用ファイバと照明 用ファイバを有する軟性鏡と, 直線状の固定光学系を有す る硬性鏡の二種がある。レーザー治療の適用が多いのは,

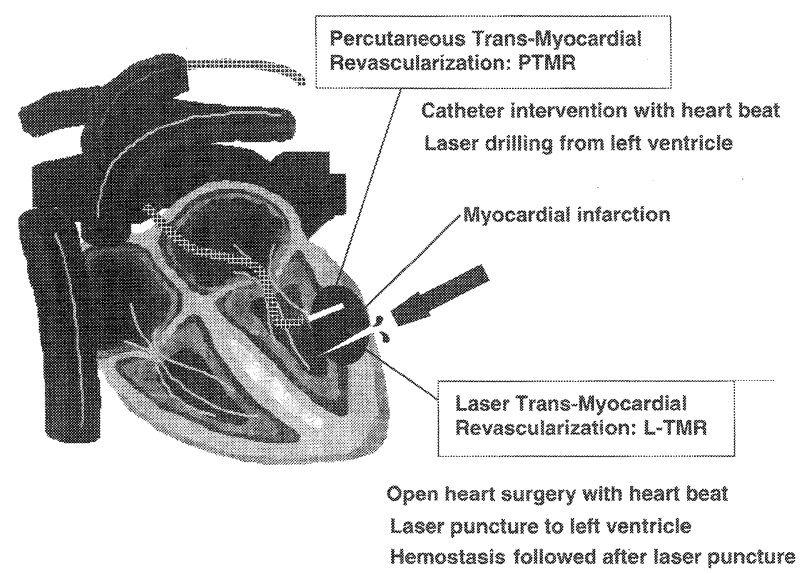

Fig.6 Diagrams of L-TMR (Laser-Trans-Myocardial Revascularization) and PTMR (Percutaneous TransMyocardial Revascularization).
Acute phase:

just after therapy

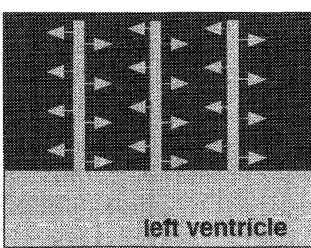

Direct irrigation from left ventricle

Fig.7 Possible mechanisms for L-TMR (Laser-TransMyocardial Revascularization) and PTMR (Percutaneous Trans-Myocardial Revascularization).

軟性鏡では上部消化管内視鏡 (胃ファイバスコープ, 胃電子 スコープ)や気管支鏡, また硬性鏡では腹腔鏡である、レー ザー光のファイバ伝送が重要となるのは, 前者の軟性内視 鏡下手術である。上部消化管領域では, 従来から凝固止血 や早期癌の熱凝固療法に用いられてきたNd:YAGレーザー に加えて, $\mathrm{CO}_{2}$ レーザー, 半導体レーザー, Ho:YAGレーザー を内視鏡の鉗子孔(内径約 $2.2 \mathrm{~mm}$ ) を通してファイバ伝送し て使用でき, 凝固治療に加えて蒸散治療が選択できるよう になった，これに基づき荒井らは, 半導体レーザーと緑色 の検査薬 (ICG: Indocyanine green)の局注を用いた早期癌の 選択的蒸散治療法を検討している ${ }^{12)}$. ICGは生体内におい て $805 \mathrm{~nm}$ に吸収極大を持ち, $800 \mathrm{~nm}$ 帯半導体レーザーの吸 収修飾薬剂として重要である。さらに癌標識抗体を持つ ICGも検討されており, 半導体レーザーとICGを組み合わせ た診断・選択治療は新しい展開を見せている13).

また気管支鏡下, 消化器内視鏡下で光化学癌治療 (PDT: Photo-Dynamic Therapy)が実用化している. 現在認可され ているのは, Photofrin II ${ }^{\circledR}$ と呼ばれる光感受性薬㓮をエキシ マレーザー励起色素レーザー $(630 \mathrm{~nm})$ で励起する治療であ り, 対象は早期癌である (Fig.8 $)^{14)}$. 副作用が少なく, 深部 治療に有効な次世代薬剤や新しい励起用光源 $(664 \mathrm{~nm}$ GaAlAs半導体レーザー, OPO: Optical Parametric Oscillator など)が続々と開発されており, 将来, 進行癌から癌予防ま で広範な対象に実用化されると期待できる15)。一方, 画像

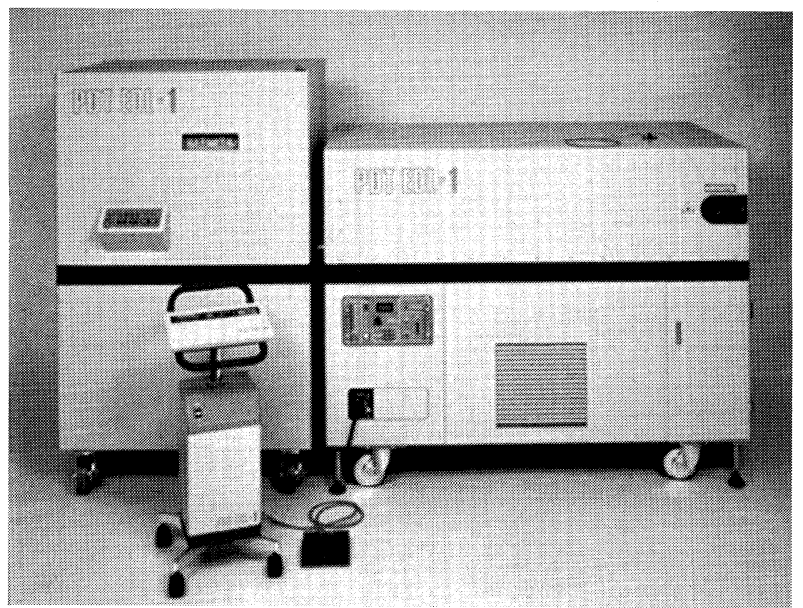

Fig.8 Photograph of the excimer-laser-pumped dye laser for PDT (PhotoDynamic Therapy) (PDT EDL-1, Hamamatsu Photonics). 
ファイバに石英イメージファイバを用いた, 細径内視鏡が 実用化され, 内視鏡下レーザー治療の対象が乳管, 唾管, 膵 管などの細径管腔(直径1２.5mm)にまで拡がっている16).

\section{3 穿刺治療}

アプローチに管腔や血管が利用できない春椎などの治 療に, 穿刺によるアプローチが用いられる、細い穿刺針(内 径 $<400 \mu \mathrm{m})$ を通して治療できるのは, ファイバの細径性 に負うところが大きい. 脊椎で行われているのは,へルニ ア治療のための髄核蒸散術 (PLDD: Percutaneous Laser Disk Decompression)である (Fig.9 ${ }^{17)}$. 石英ファイバ伝送した Ho:YAGレーザー光, Nd:YAGレーザー光等で髄核内に空洞 を開け, 椎間板内压力を下げてへルニアの脱出を抑制し神 経への圧迫を軽減させる治療で, 従来法よりも細い穿刺針 を使用できるので侵襲が小さいのが特長である. Ho:YAG

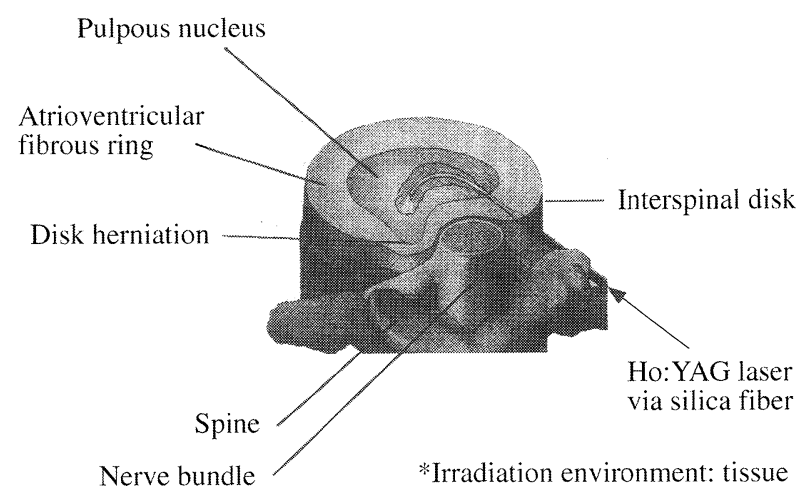

Fig.9 Diagram of PLDD (Percutaneous Laser Disk Decompression).

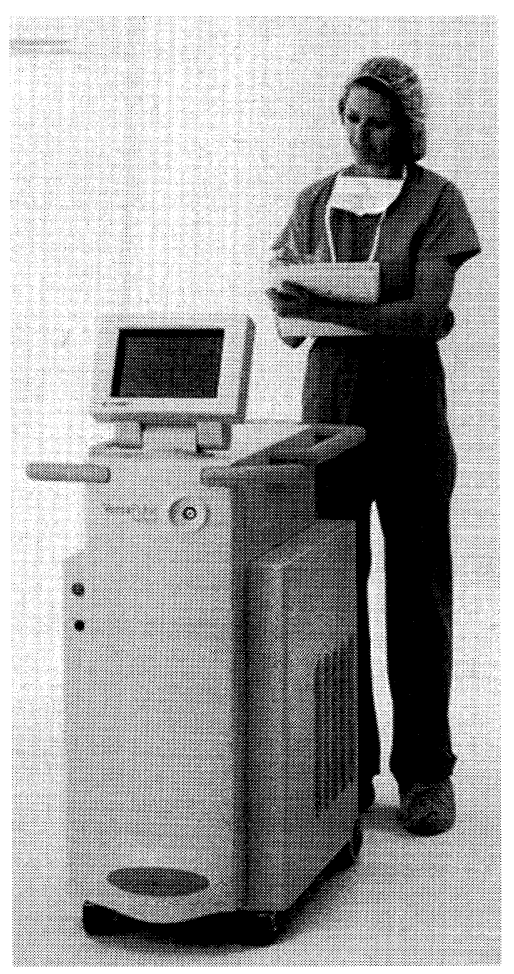

Fig.10 Photograph of the surgical Ho:YAG laser with a low-OH silica glass fiber (VersaPulse Select, Coherent).
レーザー手術装置は軟組織に加えて,このような軟骨組織 も治療でき, 整形外科領域において適応の広い治療器であ る(Fig.10).

従来の前立腺肥大の治療は, 尿道側から(尿道壁を含め て) 前立腺を切除する侵襲の大きいものである，低侵襲の 前立腺組織内レーザー凝固術 (ILCP: Interstitial Laser Coagulation of Prostate) が実用化している(Fig.11) ${ }^{18)}$. 硬性膀胱 鏡で尿道内腔に達した後, 膀胱鏡先端から前立腺内に穿刺 針を刺入して, 石英ファイバ伝送した $800 \mathrm{~nm}$ 帯の半導体 レーザー（5２0W）を拡散チップを通して照射する．前立 腺組織を熱凝固・壊死させ, 前立腺体積を小さくして尿道 内腔の拡大を図る。穿刺の利点は, 組織内加温と, 安定し た治療位置決めである，尿道壁をほとんど傷つけないた めに術後の痛み, 感染症などを無くすことができる，もう 一つの低侵襲治療として経尿道的レーザー高温度療法 (TransUrethral Balloon Thermotherapy: TUBAL-T)がある. 位置決め用に2個のバルーンが付いたカテーテルを使用し, 前立腺部分の尿道から拡散チップを通してNd:YAGレー ザーを照射し, 前立腺組織を $45^{\circ} \mathrm{C}$ 程度に加温して壞死させ る。このとき尿道が傷害を受けないように尿道部分のバ ルーンを水冷する (Fig.11).

\section{4. 計測・診断への応用}

最近, optical biopsyという技術が大変注目されている. biopsy (生検) とは, 生体組織を一部切除, 採取し, 顕微鏡な どを用いて病気の診断(病理診断)を行うことを言うが, 光 を用いてこれをin vivo(生体内で), 無侵襲に行うのがoptical biopsyである。ここではファイバを用いて体内の病理 診断を行う重要な例として, 蛍光分光診断と光コヒーレン ストモグラフィー(OCT: Optical Coherence Tomography)に ついて述べる.

\section{1 蛍光分光診断}

生体組織をレーザー光により励起すると蛍光を発生す る場合があるが, 病変組織が正常組織と異なる特性の蛍光 を発すれば,これを検知して病変部を特定することが可能 である。このような蛍光分光分析は感度が高く, 癌など悪

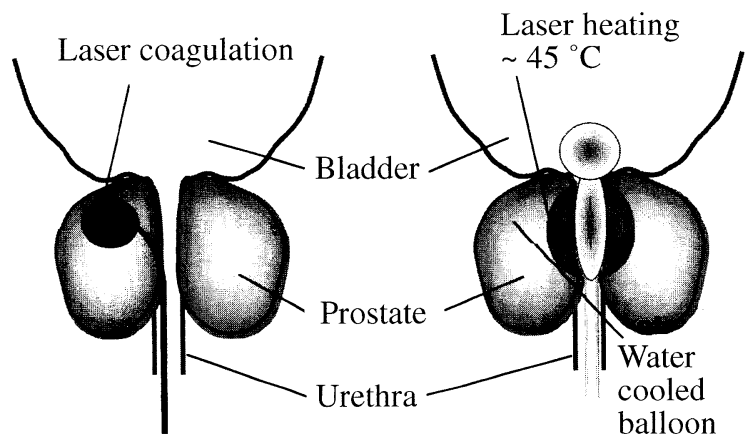

Interstitial Laser Coagulation of Prostate: ILCP

TransUrethral Balloon Thermotherapy: TUBAL-T

Fig.11 Diagrams of ILCP (Interstitial Laser Coagulation of Prostate) and TUBAL-T (TransUrethral Balloon Thermotherapy). 
性腫瘍の早期発見への応用が注目されている。患者に腫 瘍親和性のある(腫痬に集積しやすい)光感受性薬剤を静脈 注射した後にレーザー照射して蛍光を観察する場合と ${ }^{19)}$, このような薬剤は用いずに自家蛍光 (autofluorescence) を観 測する場合の二通りがあるが,ここでは後者について紹介 する。

Fig.12に肺組織を波長442nmのHe-Cdレーザーで励起し た場合の, 正常組織と癌組織の蛍光スペクトルの比較を示 す20)。これより, 正常組織は520nm付近にピークを有する 強い蛍光を発するのに対し, 癌組織は比較的波長依存性の 小さい弱い蛍光を発することがわかる，従って，例えば緑 色と赤色の蛍光強度比を計測すると, 癌病変部においては この比が小さくなるため識別が可能となる。

このような原理に基づいた早期肺癌の検知を目的とし た気管支内視鏡用蛍光観察装置が実用化されている (Fig.13).これは出力90-150mWの442nm He-Cdレーザー励 起光をファイバ伝送して肺組織に照射し(照射出力 15 $30 \mathrm{~mW})$, 自家蛍光像を通常の気管支内視鏡と高感度カメラ により撮影し，画像処理して病変部を特定するものであ る. 励起光伝送用, 蛍光画像伝送用の何れも多成分ガラス ファイババンドルが用いられている。

\section{2 光コヒーレンストモグラフィー (OCT)}

光を用いた生体情報の可視化, 画像化技術の中で, 低コ ヒーレンス干渉法を用いたOCT (Optical Coherence Tomography)が, 生体組織のin vivo高分解断層イメージングが可 能なため注目されている。マイケルソン干渉計の原理を 用いるが,これをファイバ型とすることにより,内視鏡的に リアルタイムの断層撮影を行うことができる(Fig.14) ${ }^{21,22)}$. 光を信号光と参照光に分割し, 信号光を組織内に集光照射 することにより得られる後方散乱光を, 全反射ミラーによ り反射された参照光と合成することによりへテロダイン 検出する．参照光用全反射ミラーを光軸方向に移動する ことにより組織深さ方向のスキャンを，また照射光(信号 光）を移動させることにより組織横方向のスキャンを行い, 各位置における後方散乱光の強度と遅延時間を測定す

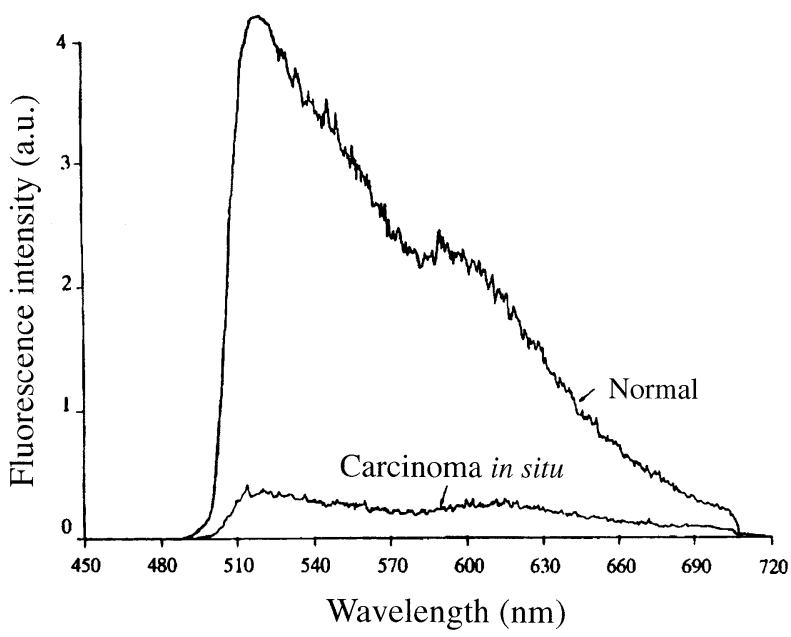

Fig.12 In vivo autofluorescence spectra for normal bronchus and carcinoma in situ lesion excited at 442 nm by using a $\mathrm{He}-\mathrm{Cd}$ laser. ${ }^{20)}$

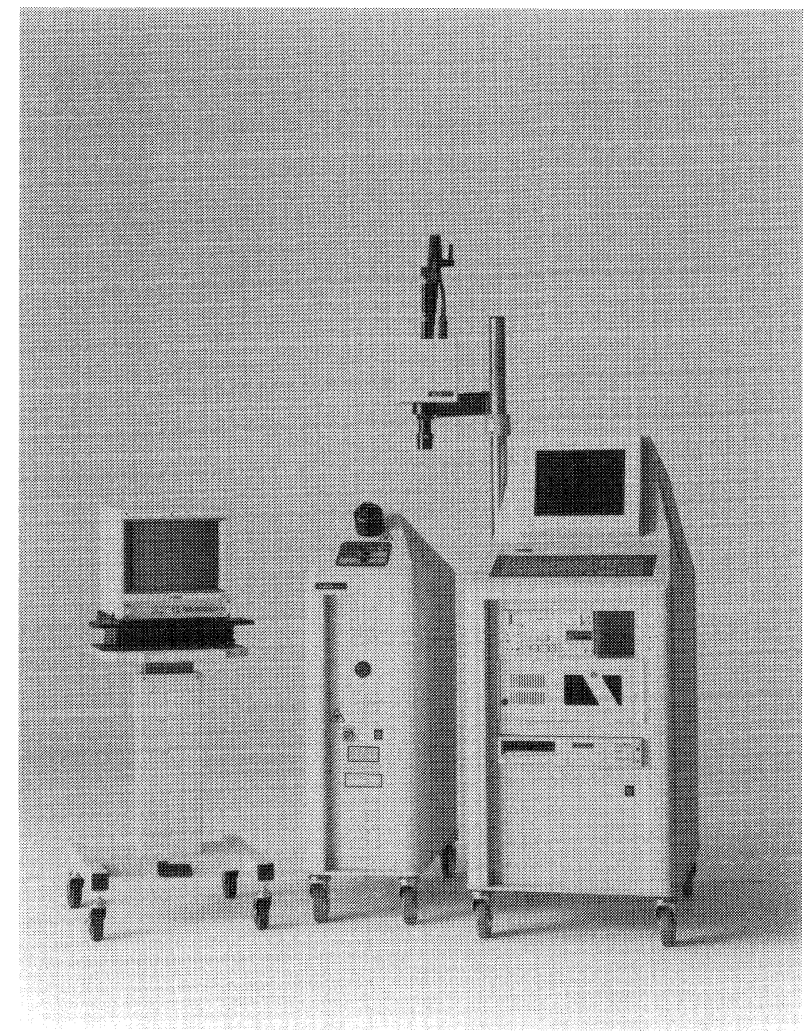

Fig.13 Photograph of the lung imaging fluorescence endoscope device (Xillix LIFE-Lung System, Olympus).

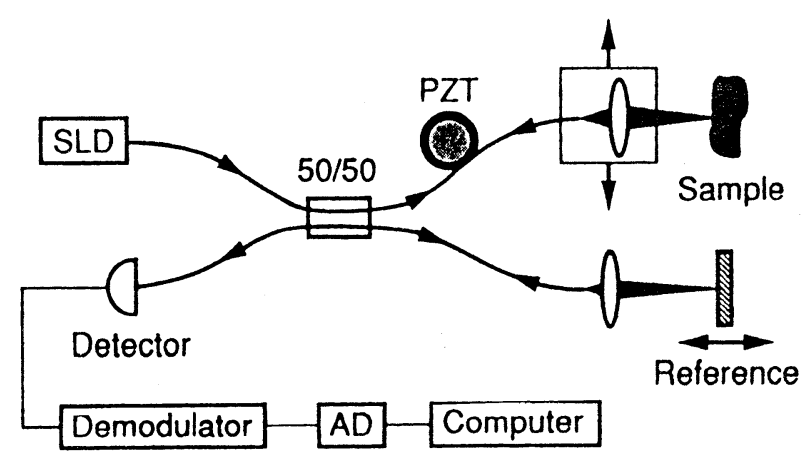

Fig.14 Diagram of OCT (Optical Coherence Tomography). An 830-nm SLD (Superluminescent Diode) is used as a low-coherence light source. ${ }^{21)}$

る，遅延時間は位置情報を含むため,その関数として散乱 光強度を表示すると断層情報が得られる。干渉信号は信 号光と参照光の遅延時間がほぼ一致したときのみに観測 されるが, 光のコヒーレンス長が短いと, 信号強度は時間 のズレに対し急速に低下する。このため組織深さ方向の 空間分解能は用いる光のコヒーレンス長により決まり（低 コヒーレンスの方が高分解能), 光源としてスーパールミ ネッセントダイオード (SLD)を用いた場合 $10 \mu \mathrm{m}$ 程度が得 られる。従来のX線CT, 磁気共鳴イメージング (MRI), 超音 波エコーなどの断層イメージングの分解能は $100 \mu \mathrm{m} \sim 1 \mathrm{~mm}$ 程度であるため, このOCTが癌の早期発見等に応用できる ものとして期待される。 


\section{5. おわりに}

最近, 医療現場においては, QOL (Quality of Life)の維持 が非常に重要視されるようになってきた。これは病気は ただ治療すればよいというのではなく, 治療後も患者が質 の高い生活を送れるようにすることが重要であるという 考え方である。その実現には多角的な取り組みが必要で あるが, 治療や診断の低侵襲化, 無侵襲化が大きな貢献を することは論を待たない. その手段として, 光ファイバを 用いたレーザー治療, レーザー診断技術の重要性は, 今後 高まることこそあれ減ずることはないであろう。医学者 と工学者の協力によるこれら技術の発展を期待したい.

\section{参考文献}

1) R. S. Taylor and K. E. Leopold: Proc. SPIE 1201 (1990) 267.

2) 小原實, 荒井恒憲, 緑川 克美：レーザ応用工学 (コロナ社, 1998) p.205.

3) T. Goldenberg, W. B. Anderson, S. H. Kupfer, H. L. Narciso, S. Shaolian, J. B. Laudenslager, F. Litvack, W. S. Grundfest, L. Adler, and J. Forrester: Proc. SPIE 1067 (1989) 145.

4) Y. Matsuura and M. Miyagi: Proc. SPIE 3092 (1996) 120.

5) Y. Shi, Y. Wang, Y. Abe, Y. Matsuura, M. Miyagi, S. Sato, M. Taniwaki, and H. Uyama: Appl. Opt. 37 (1998) 7758.

6) 安藤 嘉則, 青木 章, 山田敏元, 大野 純一, 渡辺久, 田上順次, 石川烈：日本レーザー歯学会誌 7 (1996) 58.

7）萱島一弘, 大嶋 希代子, 立石 文和, 菅田 文雄：応用物理 59
(1990) 1674.

8) U. S. Satyam, S. Shearin, and S. A. Prahl: Proc. SPIE 2970 (1997) 19.

9) E. D. Jansen, M. Frenz, K. A. Kadipasaoglu, T. J. Pfefer, H. J. Altermatt, M. Motamedi, and A. J. Welch: Ann. Thorac. Surg. 63 (1997) 640.

10) C. B. Kim, R. Kesten, M. Javier, M. Hayase, A. S. Walton, M. E. Billingham, R. Kernoff, and S. N. Oesterle: Catheterization and Cardiovascular Diagnosis 40 (1997) 223.

11) N. Gassler, H. O. Wintzer, H. M. Stubbe, A. Wullbrand, and U. Helmchen: Circulation 95 (1997) 371.

12）林 环也, 荒井 恒憲, 田尻久雄, 黑木 雅彦, 下屋 正則, 青野 茂明, 小林正彦, 永尾重昭, 宮原透, 日野邦彦, 菊地眞, 丹羽 寬文：Gastroenterological Endoscopy 39 (1997) 1753.

13）伊東進, 六車直樹, 林重仁, 梯泰昌, 筒井朱美, 清水一郎: 日本内科学会雑誌 85 臨時増刊 (1996) 252 .

14）三村征四郎, 大谷透, 奥田茂：日本レーザー医学会誌 15 (1994) 29.

15) 奥仲哲弥, 加藤 治文, 小中 千守, 土田敬明, 日吉 利光, 勝海 東一郎, 原田匡彦, 筒井 英光, 司馬清輝: 日本レーザー医学 会誌 15 (1994) 21.

16）岡崎 亮：先端医療 5 (1998) 86.

17) D. S. J. Choy, P. W. Ascher, S. Saddekni, D. Alkaitis, W. Lieber, J. Hughes, S. Diwan, and P. Altman: Spine 17 (1992) 949.

18）ジャン・ドウ・ラ・ロゼット：泌尿器外科 10 (1997) 695 .

19）會澤勝夫, 黒沢寛史：レーザー研究 25 (1997) 213.

20) J. Hung, S. Lam, J. C. LeRiche, and B. Palcic: Lasers in Surgery and Medicine 11 (1991) 99.

21) D. Hung, E. A. Swanson, C. P. Lin, J. S. Schuman, W. G. Stinson, W. Chang, M. R. Hee, T. Flotte, K. Gregory, C. A. Puliafito, and J. A. Fujimoto: Science 254 (1991) 1178.

22) G. J. Tearney, M. E. Brezinski, B. E. Bouma, S. A. Boppart, C. Pitris, J. F. Southern, and J. A. Fujimoto: Science 276 (1997) 2037. 医用レーザー(medical laser)

治療や医用計測・診断に用いるレーザー装置。治療用 としては, $10.6 \mu \mathrm{m} \mathrm{CO}_{2}$ レーザー(切開), 1.06 $\mu \mathrm{m} \mathrm{Nd:YAGレー}$ ザー(凝固・止血), $488 \mathrm{~nm}, 514.5 \mathrm{~nm}$ Arイオンレーザー(網 膜凝固), 694nmルビーレーザー(あざ治療) などが早くから 実用化されている(カッコ内は主な利用法)。最近では, 193nm ArFエキシマレーザー (近視治療), 2.1 $1 \mu \mathrm{m} \mathrm{Ho}: \mathrm{YAG}$ レーザー(内視鏡下手術, 結石破砕), $2.94 \mu \mathrm{m}$ Er:YAGレー ザー(䠘歯治療), 532nm第二次高調波Nd:YAGレーザー(内
視鏡下手術), $800 \mathrm{~nm}$ 帯半導体レーザー (一般外科, 内視鏡下 手術)なども実用化されている．また癌の光化学的治療に 用いる半導体レーザーやOPO (光パラメトリック発振器) の開発も進められている。医用計測・診断用としては ドップラー血流計に632.8nm He-Neレーザー, 血液酸素化 度計測装置に半導体レーザー, 蛍光分光診断装置に $442 \mathrm{~nm}$ He-Cdレーザーなどが用いられている。（佐藤俊一）

\section{コリメーション (collimation)}

レンズ等を用いて平行光線束を得ること．点光源から 出た光を集光して再び一点に集める場合, 通常, 2枚のレン ズを用いる．1枚目のレンズで平行光線束を作り,2枚目の レンズで一点に集める、いずれのレンズの働きも日本語 では「集光」と表現できるが, 英語では前者を「collimation」, 後者を「focusing」と明確に区別して表現できる。レンズ以 外にも凹面鏡や回折光学素子を用いることができる。コ リメーションを行った後レンズで絞ってピンホールを通
し, 再びコリメーションを行うと, 紛れ込んでいた迷光を 取り除くことができる. 分光器の内部では, プリズムやグ レーティング等の分散体に光を通す前にコリメーション を行う。ビームエキスパンダを用いてビーム径の大きな 平行光線束に変換すると, ビーム拡がり角の小さな光線束 が得られ，遠くまで進んでもビーム径があまり拡がらない ため,レーザーレーダーに利用される。

(山口哲) 